Article

\title{
Strategy for the Appropriation of a DSS in Small Bovine Producers Using Simulation and a Serious Video Game
}

\author{
Urbano Gómez-Prada ${ }^{1,2, *(\mathbb{D})}$, Martha Orellana-Hernández ${ }^{3}$ (D) and Jesús Salinas-Ibáñez ${ }^{2}$ (D) \\ 1 Faculty of Systems Engineering, Engineering School, Bolivarian Pontifical University, \\ Bucaramanga 680011, Colombia \\ 2 Institute for Educational Research and Innovation (IRIE), University of the Balearic Islands, \\ 07122 Palma, Spain; jesus.salinas@uib.es \\ 3 Unab Creative, Autonomous University of Bucaramanga, Bucaramanga 680003, Colombia; \\ morellana@unab.edu.co \\ * Correspondence: urbano.gomez@upb.edu.co; Tel.: +57-7-3167502899
}

Received: 14 October 2020; Accepted: 26 November 2020; Published: 2 December 2020

check for updates

\begin{abstract}
There is low adoption of Information Technologies (IT) in the administration of small bovine production systems which causes that most decisions are made based on the experience of the administrators and not based on data. This study proposes a methodological strategy to improve the adoption and appropriation of a Decision Support System (DSS) in the aforementioned kind of systems. The strategy includes gamification elements in the training supported in three IT tools, which help with the understanding of the connection between the tools. The tools are a simulation model, a serious video game, and the DSS. The design and development of the strategy used Design and Development Research and Case Study, System Dynamics to develop the simulation model and a Rational Unified Process to develop the serious video game and the DSS. The methodology was implemented in Santander, Colombia with informative sessions and working with producers in aided simulated environments with the goal of getting participants to use the proposed tools in their environments in a voluntary, autonomous, lasting way. Results showed the impact of the ludic and pedagogical components for the appropriation of the technology. 22 months after finishing the aided sessions $34 \%$ of the farmers show appropriation of the DSS and use it on their farms.
\end{abstract}

Keywords: appropriation; bovine production system; decision support system; serious video game; System Dynamics; strategy

\section{Introduction}

Bovine production is an economic activity aimed at generating products, such as meat and milk for human consumption [1]. Interactions among the components of the production system generate information that managers must take into account to make decisions [2] and decrease uncertainty to improve profits from their activities [3]. However, there are few strategies that involve the adoption of information technologies (IT) for these producers [4,5]. Taking this into account, the proposed strategy seeks that farmers understand that their farms can be considered as systems and their choices should be based on data to improve their results.

Small bovine producers are people who work in the management of cattle to produce meat and milk, have social and demographic factors that require improvement, and generally do not use information systems for the administration of their systems because of cultural rooting and resistance to change among other reasons [6]. Because of that they must be trained in better agricultural practices that would allow them to have access to more information about their processes [7], reduce errors and 
unwanted delays in their decision making, improve the efficiency of their processes [8], and improve their economic results. To achieve this it is necessary to change certain behavioral patterns that involve personal, social, cultural, and structural factors which will allow modernization of the agroindustry [9].

One-third of the land in Colombia is devoted to cattle farming (livestock production systems and grasslands have expanded from 14.6 to 24 million hectares, $21 \%$ of the national area) [10]. Colombia is emerging from conflict and changes are necessary to improve rural livelihoods in its agricultural sector. This can be achieved by implementing programs of agricultural strengthening originating from the autonomous work of the community with accompaniment in a diverse multicultural scenario where knowledge and collaboration are promoted by integrating traditional and contemporary knowledge [11]. The majority of cattle farming in the country is managed by small bovine producers who do not use technology for administration and therefore require practices that promote its use.

According to the Federación Colombiana de Ganaderos [12] a small bovine producer in Colombia is a cattle farmer whose production system, called farm, has a maximum of 25 animals and an income of less than 9000 dollars per year. These producers are organized into territorial communities that receive technical aid from public entities, which periodically provide farmers with healthcare programs for their animals or with short training activities on ways to run their processes. Most times, however, those measures are not enough to improve the profits and increase the wellness of the farmers. An example of this is the multidimensional poverty index of the rural sector of Santander, Colombia [13], which was estimated at $77.2 \%$ in 2015. This index is an indicator of the UN Human Development Report that identifies deficiencies in homes and people in terms of health, education, and quality of life and makes comparisons at regional, national, and global levels based on countries, ethnic groups, and rural or urban zones [14].

In order to provide training to use IT in the agricultural practices of small producers this study proposes a strategy of appropriation which seeks the appropriation of a Decision Support System by bovine producers. The researchers' goals are:

1. To use System Dynamics to benefit people by creating awareness of the relationship between knowledge and its applications [15] by improving farmers' perception of the intrinsic interactions or dependencies that exist among the variables of the productive system [5].

2. To contribute so that knowledge provided by models is applied in different tools [16] and so that systems thinking is integrated with Information Systems as Checkland and Ornerla [17] suggest.

3. To reduce the gap in Information Technologies in the rural sector by helping farmers to appropriate a Decision Support System for managing their farms, because while useful tools exist, farmers use few of them [18].

The strategy involves a simulation model, a serious video game, and a Decision Support System. By providing a playful pedagogical component these elements are integrated to:

1. Make training of farmers easier with their participation in defining the simulation model. This model will then provide equations that will support the two other tools: the video game and the DSS. This will improve farmers' confidence in the toolset and allow the definition of a common language used during the rest of the training and while using the tools.

2. Guide farmers on how to use the DSS by using the serious video game as a learning tool as the decisions that must be made in the game are similar to those in reality.

3. Allow farmers to make decisions about their production systems based on the information provided by the DSS about their processes autonomously and without assistance.

The strategy is connected to the suggestions of Moravec and Cobo [19] as there are practical exercises that relate to the productive work of the learners, and of Rueda and Franco [20] who state that information technologies give people productive and commercial opportunities, and therefore help with the mitigation of rural abandonment. 


\section{Concepts and Methods}

\subsection{Adoption and Appropriation of IT}

The adoption of IT can be considered as the action of involving IT tools in processes in order to change the way they are run by improving how data are obtained and processed [21]. Resistance to change, caused by users' cultural and material specific situations, must be mitigated [22] before changes to the way processes are carried out are proposed [23] to achieve it.

On the other hand, and in general, appropriation implies redefinition, reorganization, and planning of processes [24]. IT appropriation initially requires IT adoption and provides the user with skills to work with IT tools with a sense of liking the technologies and autonomy [25], allowing the user to recognize that IT satisfies individual and organizational needs and interests [26].

IT appropriation improves the results of agricultural activities and therefore improves the quality of life of the participants in the activities. It can also achieve sustainable rural transformation by strengthening commercial, interpersonal, and intercultural relations [27] given that IT challenges traditional developmental methods and ensures progress in the wellbeing of many people [28]. This is why access to IT in rural areas is important for sustainability of communities with transformative strategies.

\subsection{IT Appropriation in Industrial Agriculture}

Like any productive sector, industrial agriculture should seek the appropriation of IT due to it offering the possibility to take advantage of data by transforming them into information. The use of DSS to make predictions enhances making decisions, increases production, and improves marketing [29].

Arévalo, Bayona, and Rico [8] say that the use of IT eases the control of organizational processes by providing information to improve their efficiency. In the agricultural sector it adds value by creating the possibility of tracing data about animals from gestation to sale or consumption. The authors suggest that consequences of not using IT include errors or delays in decisions, no awareness of losses, absence of profits, abandonment and migration to urban areas.

Colombia should make efforts to seek rural development. According to the National University of Colombia [30] generating IT appropriation in farm administrators can support that development. The strategic plan of Santander, Colombia seeks to establish a road map to improve its economy and thus the quality of life of its habitants by strengthening the economic sectors found in rural areas, seeking to improve results [23].

\subsection{Bovine Production System}

A bovine production system is an organization of elements, usually called á farm, which has resources and demographic, biophysical, productive, and financial aspects that must be controlled to generate profit [31]. It is a dynamic economic activity focused on the production and marketing of agricultural products. Cattle can be used in production systems such as [32]: (1) breeding: selling animals after their lactation; (2) fattening: fattening animals until they are ready to be sold for slaughter; (3) dairy: managing the gestation for milk production. (4) full cycle: mixing between breeding, fattening and dairy.

A bovine production system depends to a high degree on external factors, but a large part of the events can be controlled and generate the need to carry out other events in future. The right decisions must be made in these events to improve the performance and efficiency of the productive system. Some examples are:

1. A birth requires: the mother's milk production to be controlled, lactation of the calf a few months after birth to be stopped, three months after giving birth the cow to be inseminated.

2. An insemination requires that the supply of milk to the calf stops after nine months.

3. Each weight record requires checking that the value is consistent according to the age and breed of the animal. 


\subsection{Simulation Models with System Dynamics}

Simulation models represent the conceptual understanding of a phenomenon. They offer the possibility of generating experiences that improve the understanding of the system based on the analyses done during its construction and the results of the simulations generated with it [33].

In this work the model was created with System Dynamics, a methodology proposed in the 1960s by Jay Forrester to analyze, build, and simulate the effects of feedback loops on the behavior of a system through mathematical models [34]. System Dynamics is used to support organizational, social, and political decisions [35].

System Dynamics is composed of five complementary languages: prose, causal loop, stock and flow, equations, and behaviors. The system is described in prose, and its structure is represented in causal loop diagrams which are then transformed into stock and flow diagrams and equations in discrete time which are then evaluated to see the behavior of the system as time passes [36].

\subsection{Serious Video Games}

Serious video games are interactive digital instruments oriented not only to entertainment as usually happens with video games, but also to training concrete skills on a topic by using game mechanics based on the processes of the represented system [37]. Serious video games ease learning by giving players the possibility of controlling variables, making decisions, developing strategies, and constantly comparing the effects of their actions on the system [38].

Serious video games can provide solutions to agricultural challenges such as transfer of knowledge and increase in productivity according to Fisher et al. [39]. The authors consider that serious video games can be used in workshops with farmers, producers, advisers, and researchers to make decisions similar to those in reality.

\subsection{Decision Support Systems (DSS)}

DSS are a special kind of information systems aimed at handling data and offering the user with decision options according to the conditions of systems, to tackle diverse problems [40]. DSS usually have three components: a database, a software system, and a user interface. DSS are supported by mathematical models and can use simulations to enhance training activities [41].

\subsection{Methodologies of Research}

The study combined four methodologies of research:

1. Design and development research was used because it is oriented to educational innovation by introducing new tools in a traditional process to transform it and advance the didactic design of its teaching-learning process [42], and therefore directs the exploration of new context-based environments for teaching and learning, applying its developmental processes to creation of products, tools, and models [43].

2. Case study was used because the authors had interest in working with communities, and each community could be considered as a unique social instance that could be analyzed to understand the way it works in order to generate hypotheses and apply proposals [44].

3. The Rational Unified Process (RUP) was followed during the phase of the study related to building tools to develop the video game and the Decision Support System. The RUP is an iterative and incremental lifecycle run in work flows that involve modeling, analysis, design, implementation, testing, and deployment [45].

4. System Dynamics was used to build the simulation model which supported the creation of the mechanics of the video game and the prognostic reports in the DSS. The methodology of System Dynamics is described in Section 2.4. 


\section{Results}

The strategy is based on the understanding and collaboration provided by simulation models which helps to understand the complexity of the production system through the communication made with the influence diagrams and the significant learning allowed based on transference and appropriation, as explained by Victoria et al. [46] and that, is in this case supported by gamification, represented in a serious game.

The proposed strategy was applied with farmers from five communities in Santander, Colombia. Each community was composed of 5-7 small bovine producers who agreed to participate in the study and whose characteristics were presented in a previous report [47].

The strategy includes training sessions in which the trainer provides a collaborative environment where farmers can verify the simulation model that contains the most representative variables of a farm as well as interactions between them. The structure of the simulation model is then integrated in the serious game which presents players with a simulated farm that must be administered so that players understand the high volume of data handled in those processes [48]. Those data can be seen in the DSS to verify results of the game and in that way learn to use the system to manage a real farm.

The strategy has been applied over 22 months in the phase in which there is no aid from the tutor and yielded $34 \%$ of farmers appropriating the DSS.

\subsection{IT Tools Developed for the Strategy}

The strategy integrates three technological tools developed for the proposal. The tools are intertwined in their functioning [48]: the events of a real farm that can be managed through the DSS correspond in most cases to the choices that players can make in the video game and the simulation model. The three IT tools unify the knowledge and align the way of carrying out the processes. Thanks to this they allow development of training sessions with farmers and the planning of productive strategies on the farm.

Those events are used and registered with the help of the tutor in three situations:

1. While participating in the collaborative definition of the model.

2. While simulating management in the video game and checking the obtained results in the DSS.

3. While managing a real farm using the DSS.

Table 1 shows the ten events of the productive system that were taken into account in the developed tools

Table 1. Events present in each of the developed tools.

\begin{tabular}{ccccc}
\hline$\#$ & Event & Simulation Model & Serious Video Game & DSS \\
\hline 1 & Weigh & $\mathrm{X}$ & $\mathrm{X}$ & $\mathrm{X}$ \\
\hline 2 & Insemination & $\mathrm{X}$ & $\mathrm{X}$ & $\mathrm{X}$ \\
\hline 3 & Birth & $\mathrm{X}$ & $\mathrm{X}$ & $\mathrm{X}$ \\
\hline 4 & Milk & $\mathrm{X}$ & $\mathrm{X}$ & $\mathrm{X}$ \\
\hline 5 & Medication & $\mathrm{X}$ & $\mathrm{X}$ & $\mathrm{X}$ \\
\hline 6 & Buying & $\mathrm{X}$ & $\mathrm{X}$ & $\mathrm{X}$ \\
\hline 7 & Selling & $\mathrm{X}$ & $\mathrm{X}$ & $\mathrm{X}$ \\
\hline 8 & Dying & $\mathrm{X}$ & $\mathrm{X}$ & $\mathrm{X}$ \\
\hline 9 & Feeding & $\mathrm{X}$ & $\mathrm{X}$ & \\
\hline 10 & Hydrating & $\mathrm{X}$ & $\mathrm{X}$ & \\
\hline
\end{tabular}

A brief description of each tool is presented below. Note that the Selling event is highlighted in figures below as an example. It is one of the ten events that exist in the three developed tools. 
Feeding and hydrating are the only two events that weren't included in the DSS. They were left for a new version because farmers do not have control over them [47], hence farmers cannot individually check the food and water since they do not have extensive production systems, which make it unfeasible.

\subsubsection{The Simulation Model}

The simulation model is a representation of a farm in System Dynamics and supports the two other tools for the knowledge it represents. The model shows the complexity of the productive system which the farmers understand. It delimits the scope of the videogame and the DSS, providing a common language used later in training with the help of IT tools.

Figure 1 shows the causal loop diagram which shows the base of the hypothesis of the proposed structural dynamic for a bovine production system. The diagram shows nine feedback loops (each with a different color and number) and the demographic, biophysical, productive, and financial aspects, each in a rectangle (there are only six age groups of female cattle in the demographic aspect for simplicity).

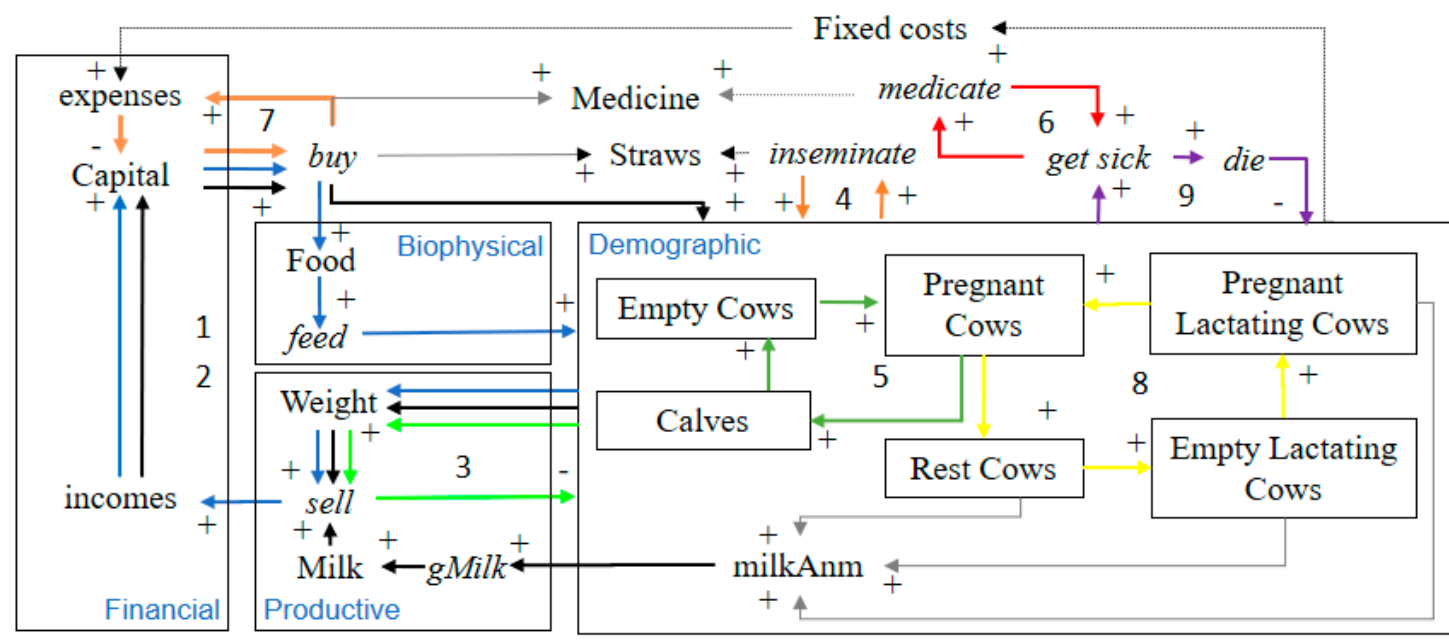

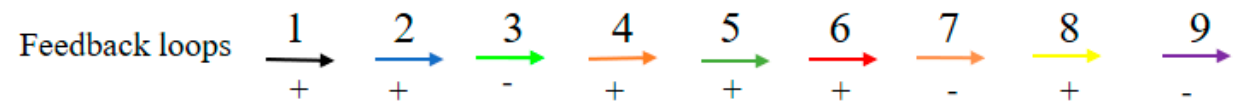

Figure 1. The first version of the simplified causal loop diagram.

Table 2 shows the description of the feedback loops.

Table 2. Feedback loops in the causal loop diagram.

\begin{tabular}{ccl}
\hline$\#$ & Loop & \multicolumn{1}{c}{ Description } \\
\hline 1 & Demographics & $\begin{array}{l}\text { Capital allows buying animals which grow and change weight and produce milk } \\
\text { that is sell to obtain income that increases capital. }\end{array}$ \\
\hline 2 & Food & $\begin{array}{l}\text { Capital allows buying food that is fed to animals so that they improve their milk } \\
\text { production or weight. Those milk and this weight can be sold to obtain income that } \\
\text { increases capital. }\end{array}$ \\
\hline 3 & Growth & $\begin{array}{l}\text { Animals increase their weight and can be sold, which decreases the number of } \\
\text { animals. }\end{array}$ \\
\hline 5 & Insemination & $\begin{array}{l}\text { Empty cow and empty lactating cow with sufficient age are inseminated to have } \\
\text { calves. This cycle requires the purchase of insemination rods and it generates } \\
\text { outcomes }\end{array}$ \\
\hline 6 & Sickness & \begin{tabular}{l} 
Animals get sick and can die, which reduces the number of animals. \\
\hline
\end{tabular} \\
\hline
\end{tabular}


Table 2. Cont.

\begin{tabular}{ccl}
\hline$\#$ & Loop & \multicolumn{1}{c}{ Description } \\
\hline 7 & Outcomes & $\begin{array}{l}\text { Outcomes reduce capital. They are generated when paying for food, insemination } \\
\text { rods, medicines, or fixed expenses. }\end{array}$ \\
\hline 8 & $\begin{array}{l}\text { The cycle starts by buying an empty cow. When it is inseminated, it changes status to } \\
\text { pregnant cow. Nine months later, the cow gives birth and changes status to cow at rest } \\
\text { for a few days. After the resting days the cow changes status to empty lactating cow, } \\
\text { and can be inseminated again to become a pregnant lactating cow. Some months } \\
\text { before giving birth the cow stops being milked and the cycle starts again. This cycle } \\
\text { can be repeated depending on the condition of the animal. }\end{array}$ \\
\hline 9 & Breeding & The Pregnant Cow gives birth to a calf. When calves grow, they become Empty Cows. \\
\hline
\end{tabular}

The model is constructed in the modeling environment: "Evolución" [49], which takes care of the simulation as a function of time. Figure 2 shows the model in the language of flow-level which requires the presentation of more elements. Medication, dying, straws, getting stick, water and fixed costs were removed from this document to simplify understanding (variables such as getting sick and dying involved adding an outflow to each level where there are animals).

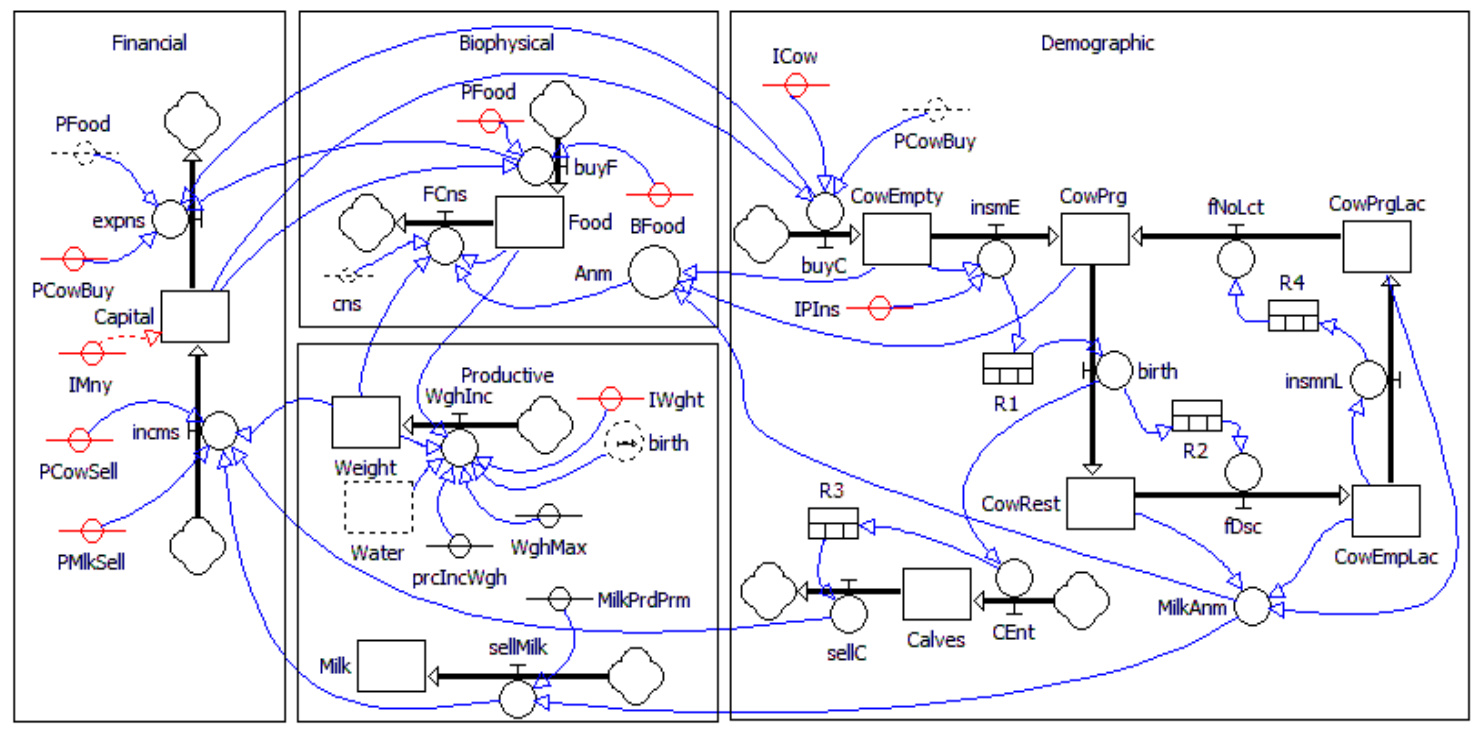

Figure 2. The simulation model in the flow-level language.

The model is transformed into equations in discrete time that are used during the creation of the video game mechanics and the production and forecasting reports of the DSS. The first version of the model had 61 elements, the updated version has 67 . Three of the equations in discrete time are presented as an example after the diagram:

1. The capital is given at the start and after it is calculated by the previous value, the incomes and expenses.

2. The incomes consist of milk, its price, the sale of calves, their price and weight.

3. The expenses are calculated for the purchase of food and empty cows.

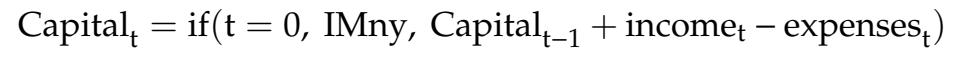

$$
\begin{aligned}
& \text { incomes }_{\mathrm{t}}=\left(\text { sellM }_{\mathrm{t}} * \text { PMilkSell }\right)+\left(\text { sellC }_{\mathrm{t}} * \text { PCowSell } * \text { Weight }_{\mathrm{t}}\right) \\
& \text { expenses }_{t}=\left(\text { buyC }_{t} * \text { PCowBuyl }\right)+\left(\text { buyF }_{t} * \text { PFood }\right)
\end{aligned}
$$


Figure 3 shows the behavior obtained from simulating a scenario where only one empty cow was purchased. The showed elements are: empty cows, pregnant cows, cows at rest, calves, weight, income and expenses. According to the letter that identifies the graph:

a. In month 1 the empty cow is bought.

b. In month 2 the cow is inseminated to become a pregnant cow (the gestation lasts 9 months).

c. In month 11 the cow gives birth and becomes a cow at rest for three months.

d. In month 11 a calf appears and is sold in month 23 .

e. The calf begins gaining weight from month 12 to 23 .

f. In month 1 an expense is generated for the purchase of the cow. From month 12 to 23, there is incomes from the sale of milk. In month 23 , the calf is sold and an income is generated from it.

a
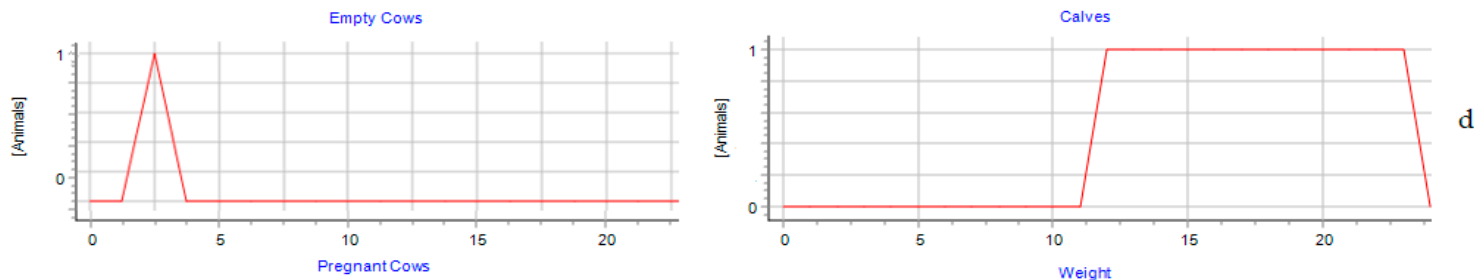

b
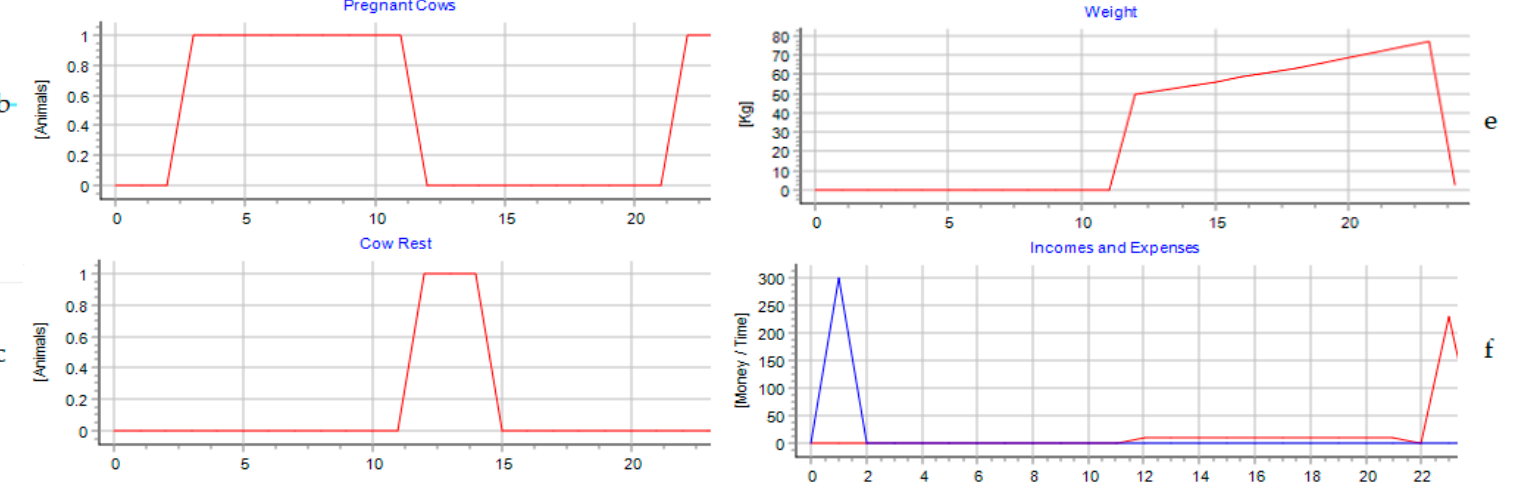

Figure 3. Behaviors of the empty, pregnant, at rest cows, calves, weight, incomes and expenses.

\subsubsection{Serious Video Game}

The serious video game is a digital interactive representation designed for developing skills in the use of IT. The game was developed in Unity. During the game the farmer must make choices to manage a simulated farm based on an initial budget, a set of configuration parameters assigned by the tutor, and the status of the simulated cattle, which changes during the playing session.

A game in the serious video game begins with an empty stable, some starting conditions and a capital assigned for managing. The first task is to buy animals care for them, and manage the consequences of the decisions, for example the associated income and expenses.

Figure 4 shows the user interface of the video game during a playing session. The upper section displays the controls for the available events the player can trigger for the selected animals. In this session the farmer has a budget of 35,000,000 pesos (about USD $\$ 10,000$ ). 


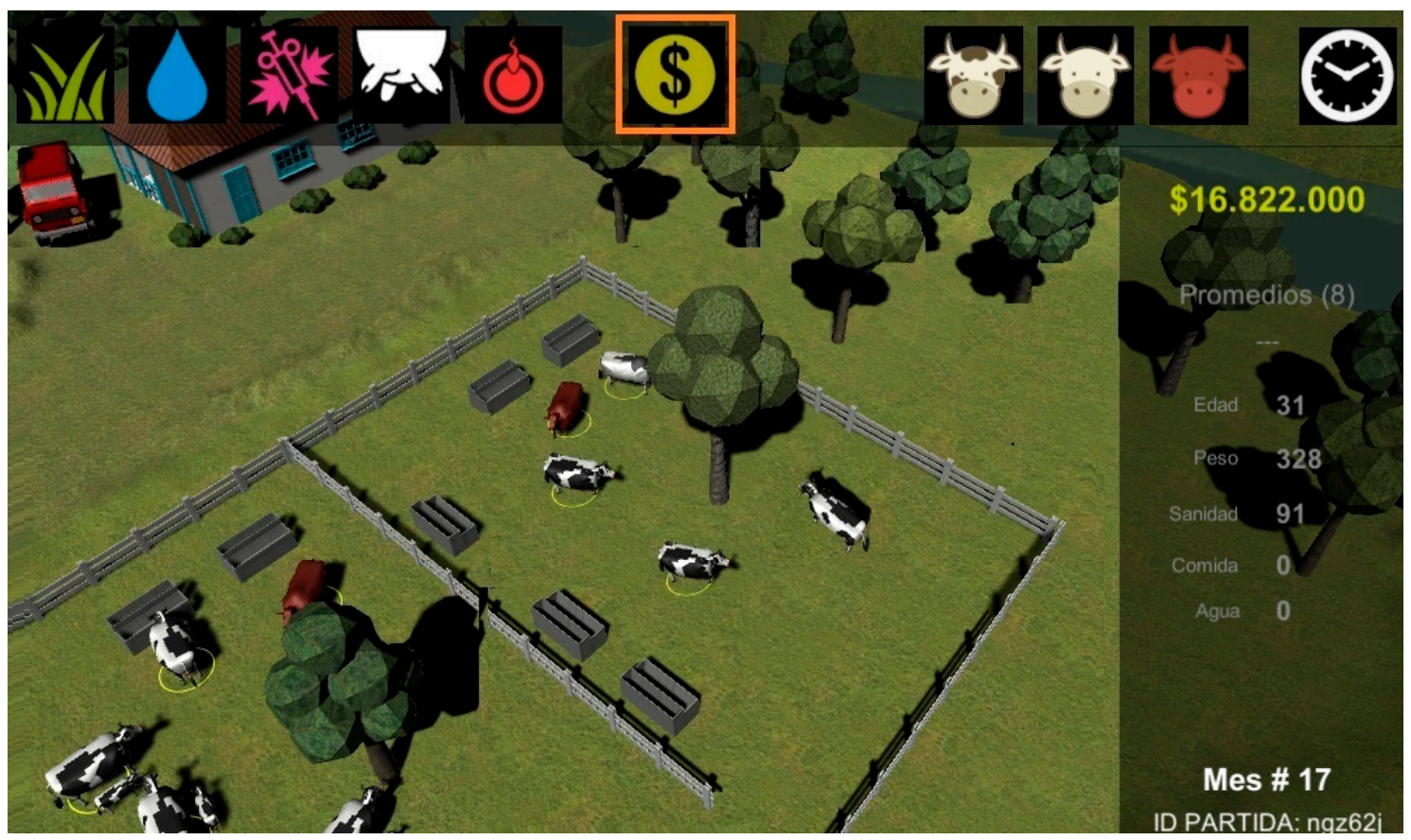

Figure 4. Example of a session of the serious video game.

\subsubsection{DSS}

The DSS is a web and mobile information system that allows the user to manage the information of the events on the farm and forecast other events based on the information. The DSS can work with data from a simulated or real farm and includes reports that allow the authors to track how much the DSS and the video game are being used by farmers. The DSS has thirty functionalities on its web version ( 3 and 7 also available for asynchronous use in the mobile version):

1. Management of master entities such as sellers, customers, batches, breeds and users.

2. Management of births.

3. Management of other events (i.e., weigh, insemination, milk, medication, buying, selling and dying).

4. Management of tasks to do (DSS forecasts dates of birth, weaning and insemination).

5. Report of the animal's details (it includes events such as birth, buying and other event logs).

6. Report on genealogy.

7. Report on individual production.

8. Report on consolidate production.

9. Report on income and expenditures.

10. Report on sold and dead animals.

11. Graphical report on individual production (it shows the expected weight and milk values according to age and breed) and graphic report on consolidate production.

12. Graphical report on demographic distribution.

Figure 5 shows an example of three DSS options:

a. The events report: The upper section shows the buttons the farmer can use to access other interfaces to add data for each event, and displays. The lower section shows a list of events, each one with data such as the event, number of the animal, date, value, and productive week of the animal when the event was registered.

b. The list of forecasts: The list presents a task to be performed to support process control on the farm. Each one contain: the number of activity, number of the animal, the activity performed and the date. 
c. The graphical report on individual production of weight presents the registered value and a comparison with the expected value according to the breed and productive week of the animal (the farmer must select the animal, the desired event and the date range).

d. The graphical report of consolidate production of milk presents the milk produced by all animals in a range of dates (The farmer must select the date range).
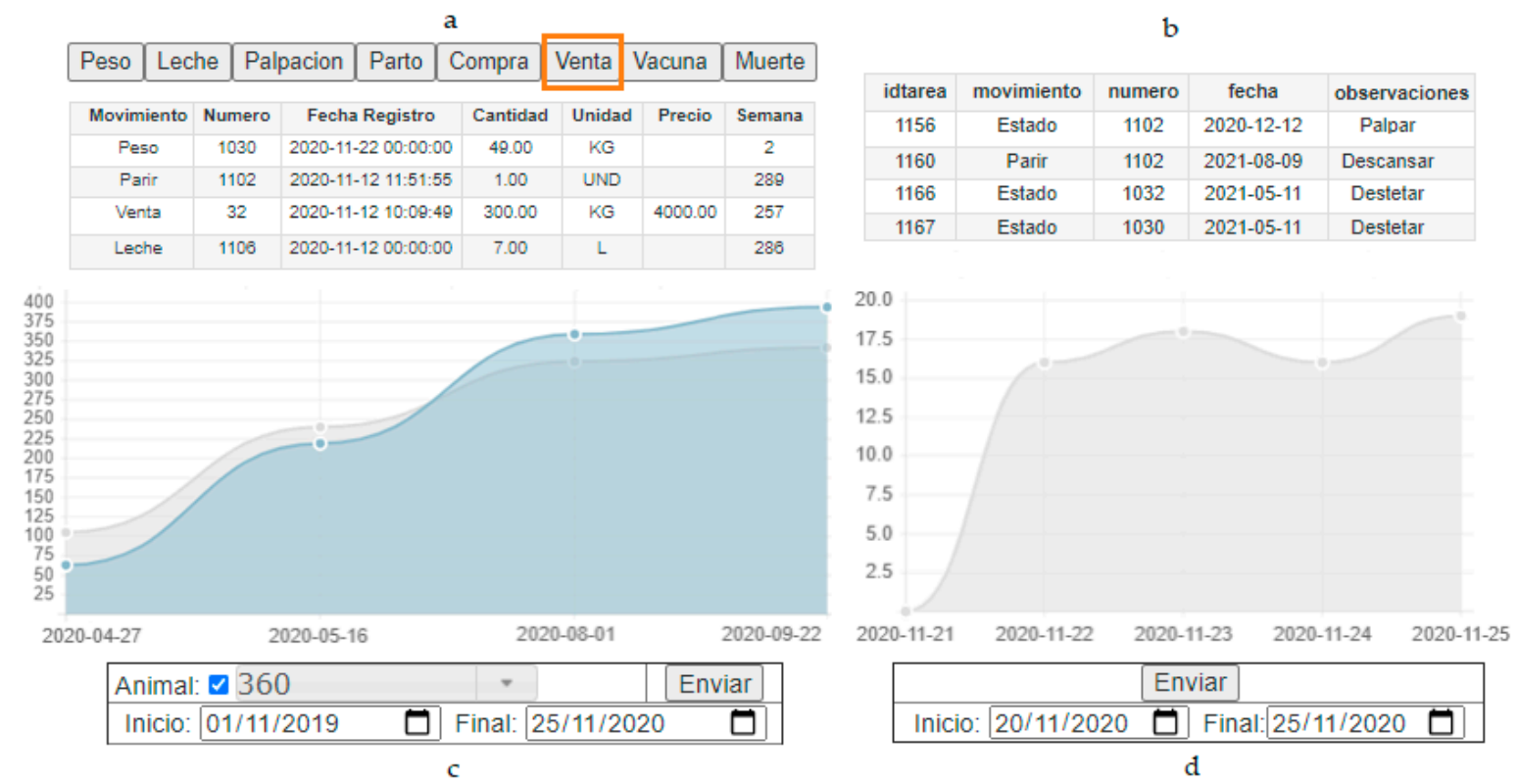

Figure 5. Example of the DSS options: events report, forecast list, Graphical report on individual production and graphical report on consolidated production (milk).

\subsection{Appropriation Strategy}

The proposed strategy was applied, improved, and validated in several training sessions with farmers from Santander, Colombia. The strategy has 10 phases, each with a purpose, and their application produces the proposed global objective: appropriation of the DSS in the producers. This is due to:

1. The farmer's participation in the collaborative construction of the model provides structure and a common language to use when using the three tools, which gives the farmers confidence and excites their interest in using them. Farmers receive training with simple models on System Dynamics so that they know the methodology, simulate scenarios in the proposed model, propose variables for a new version of the model, or approve it. At the end of this phase the tutor implements the variables that were discussed for the latest version.

2. The training sessions usually run at the local rural school, allowed the creation of collaborative spaces that unified the way of handling processes. After the sessions the farmers could help each other to solve doubts and questions about aspects of the use of the DSS that some of them forgot.

3. While the guided training process is aimed at learning how to use the tools, it improves comprehension of the benefits of having information about processes and provides practice of making decisions based on the information.

The phases of strategy are shown in Figure 6 and the purposes. The number of sessions by community (only indicated by the number of sessions in which the tutor and farmer interact personally) and the results of each phase are in Table 3. 


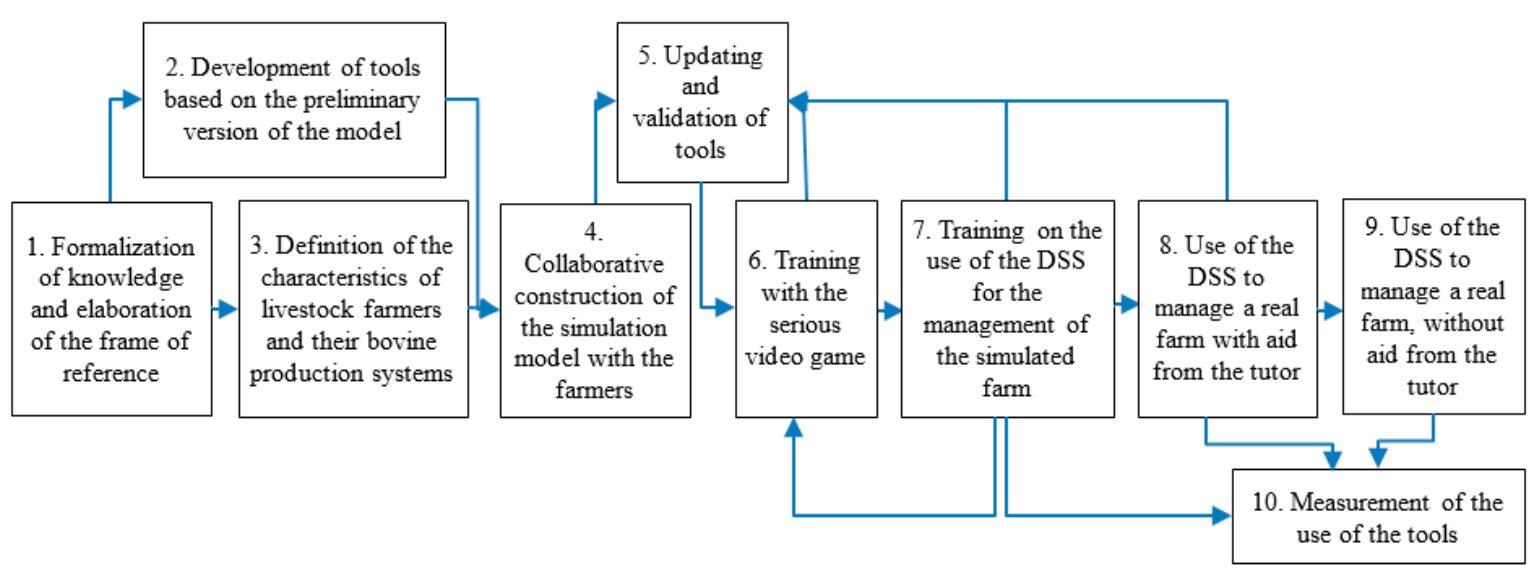

Figure 6. Scheme of the strategy.

Table 3. Description of the phases of the proposed strategy.

\begin{tabular}{llll}
\hline$\# \quad$ & \multicolumn{1}{c}{ Purposes } & \multicolumn{1}{c}{ Sessions } & \multicolumn{1}{c}{ Results } \\
\hline 1 & $\begin{array}{l}\text { To create a theoretical framework on bovine } \\
\text { production systems, System Dynamics, serious } \\
\text { video games, and DSS. } \\
\text { To review published sources on the topics } \\
\text { of interest. }\end{array}$ & $\begin{array}{l}\text { Base knowledge on animal husbandry } \\
\text { Systematic review paper based on articles } \\
\text { from Scopus and Web of Science } \\
\text { Definition of the scope of the tools }\end{array}$ \\
\hline $\begin{array}{l}\text { To develop the preliminary versions of the } \\
\text { simulation model, the serious video game, and the } \\
\text { DSS based on the created theoretical framework. }\end{array}$ & $\begin{array}{l}\text { Initial version of the model, the video game, } \\
\text { and the DSS }\end{array}$ \\
\hline $3 \quad \begin{array}{l}\text { To identify the socioeconomic status of the farmers } \\
\text { and the degree of their appropriation of IT, the } \\
\text { characteristics of the participants' farms and the } \\
\text { scope of the model by identifying new variables } \\
\text { and loops. }\end{array}$ & 1 & $\begin{array}{l}\text { Instruments for defining characteristics } \\
\text { Definition of the characteristics of the } \\
\text { farmers and their productive systems }\end{array}$ \\
\hline $\begin{array}{l}\text { To present the preliminary version of the model to } \\
\text { the farmers, as well as invite them to participate in } \\
\text { the collaborative construction of an updated model. }\end{array}$ & 2 & $\begin{array}{l}\text { Suggestions from the farmers to improve } \\
\text { the model (variables, structure, equations). }\end{array}$ \\
\hline $\begin{array}{l}\text { To update and validate the tools based on the } \\
\text { farmers' suggestions. }\end{array}$ & $\begin{array}{l}\text { To show the serious video game through } \\
\text { challenge-oriented playthroughs in which the } \\
\text { farmer must make decisions on the simulated farm } \\
\text { based on the initial money and set conditions. }\end{array}$ & Updated versions of the tools \\
\hline
\end{tabular}

To show the DSS to the farmers and motivate them to check reports about the decisions made while playing the serious video game.

$7 \quad$ To ask the farmers questions they need to answer based on the DSS. The model can be used as a reference while using the DSS so that the farmers understand how to use it and its usefulness.

\begin{tabular}{lll}
\hline 8 & $\begin{array}{l}\text { The farmers use the DSS with aid of the tutor to } \\
\text { administer their real farm. }\end{array}$ & $\begin{array}{l}\text { Production reports about the animals, the } \\
\text { processes, and the forecasts. }\end{array}$ \\
\hline 9 & $\begin{array}{l}\text { The farmers use the DSS autonomously (without } \\
\text { the aid from the tutor) on their real farms. }\end{array}$ & $\begin{array}{l}\text { Tracking reports. } \\
\text { Results of acceptance of the DSS and } \\
\text { abandonment of the strategy. } \\
\text { Measurements of the achieved levels of } \\
\text { appropriation. }\end{array}$ \\
\hline $10 \quad \begin{array}{l}\text { To measure appropriation based on usage reports } \\
\text { from the DSS (parallel to phase 9). }\end{array}$ & $\begin{array}{l}\text { Poll the farmers about their acceptance of the DSS } \\
\text { or their abandonment of the strategy according to } \\
\text { their degree of appropriation }\end{array}$ & 1
\end{tabular}


The sessions of phases 6 and 7 followed the steps presented in Section 3.2.1 (to simulate the management of a farm with the serious video game) and Section 3.2.2 (to manage the real farm with the help of the tutor).

\subsubsection{Steps of Phase 6-Training with the Game}

The sessions with the video game of phase 6 followed these steps which are shown in Figure 7 (the process is repeated as many times as required according to the skill of the farmer):

1. The tutor defines a scenario or challenge in the video game and invites farmers to start the game

2. The farmer simulates his farm and makes choices based on the proposed challenge.

3. The farmer continues to make decisions based on the results he obtains.

4. The tutor aids the farmer by posing questions about the administration of the farm: when is the ideal date for a cow to give birth, what is the ideal weight of an animal for its age, how much milk should an animal produce, etc. In some cases, the number of animals in the virtual farm caused the farmers not to answer correctly due to the fact that they forgot to contemplate factors such as: the amount of milk produced, the time of insemination and the number of times it has given birth, among other things. The farmer must therefore consult the game reports that the DSS generates and there they will find different answers.

5. Steps 2,3, and 4 are repeated until the game is over.

6. The farmer uses the DSS to solve pending questions by using the productivity reports the DSS generates. Based on the DSS the tutor, provides feedback about the decisions made in the game so that the farmer can better understand the way he should operate the system.

7. In the next sessions, steps 2 to 6 are repeated as practicing.

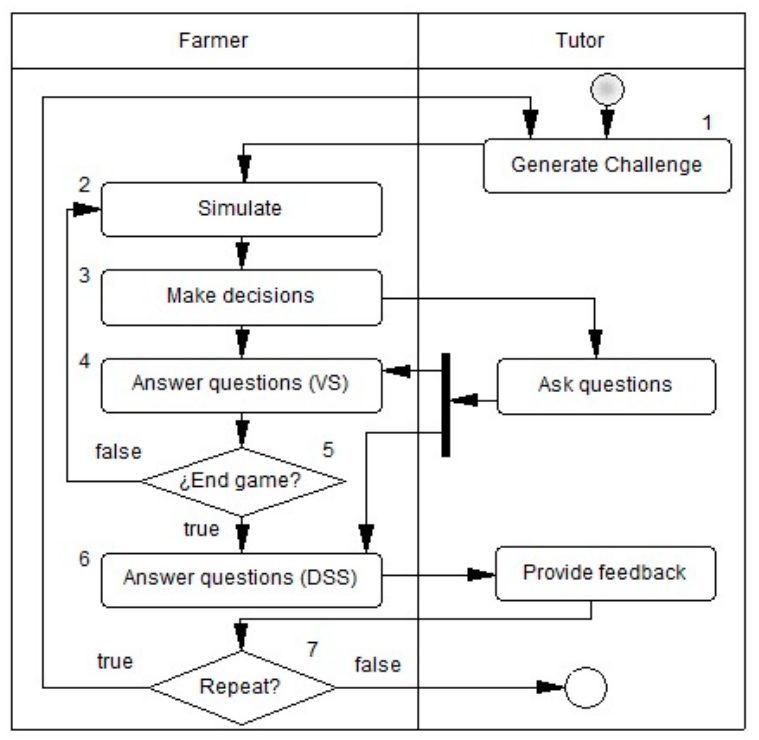

Figure 7. Steps of phase 6-Training with the game.

\subsubsection{Steps of Phase 7-Managing a Real Farm with the Help of the Tutor}

After ending the training with the serious video game, the farmer finds it easier to start using the DSS to manage the data from the real farm. This is for several reasons: he trusts the tutor, the UI uses the same events as the video game, and the farmer knows how to generate reports. The sessions in phase 7 followed these steps shown in Figure 8:

1. While the farmer is watching, the tutor sets up the system with the required parameters: data about the farm, the terrain, at least one seller or buyer, and a bull. 
2. The farmer gets to know the administrative options, fills in and checks data.

3. The farmer adds data for an animal and a weighting event and loads a report to verify the information. If the farm produces milk, the farmer must add the data of the last birth, starting with the data on the pregnant cow, the birth, and the obtained amount of milk.

4. The tutor aids the farmer when necessary while the farmer improves his skills of using the DSS.

5. The farmer checks the productivity reports and forecasts in order to get used to them.

6. In the next sessions, steps 3, 4, and 5 are repeated as practicing. When the farmer gets enough skill in the system, the tutor stops aiding him so that the farmer use the DSS autonomously.

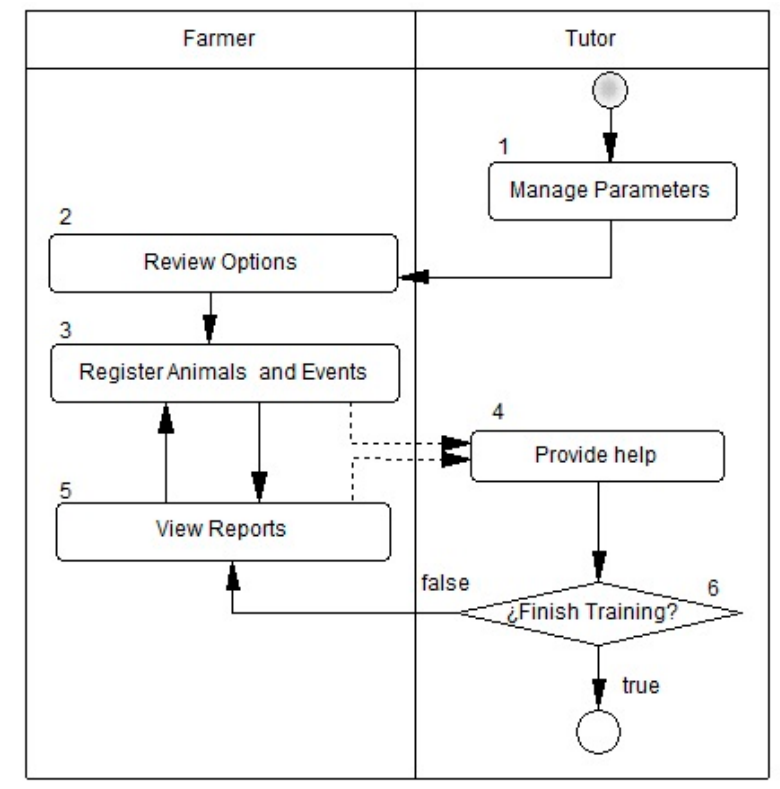

Figure 8. Steps of phase 7-Training with DSS on a real farm.

\subsection{Learned Lessons and Recommendations of the Implementation of the Strategy}

The strategy starts with some required knowledge of the system to model, System Dynamics, serious video games, and DSS (phase 1). The strategy suggests developing a first version of the tools (phase 2) to have a clearer vision of the scope, define basic equations for the video game, and set an initial set of transactions, reports, and forecasts in the DSS. Having this initial version reduces development time and therefore the time between the training sessions that use the model and the training sessions that use the video game and the DSS. This reduces the risk of participants forgetting what they learned or even changing their system, which is common in small bovine producers.

The three tools are validated with a common set of data on some animals according to the productive processes of the farm, for example insemination, reproduction, and growth (phase 5). New features were defined during the validation activities which were added in the updated version of the tools. Some of the new features are the report on incomes and outcomes and some extra filters in the existing reports to ease search for information. It was useful to use the same testing data set in the training sessions, the challenges proposed in the video game, and the demonstration of the DSS so that farmers could understand the parallelism between the tools. The data used for this project were provided by a farmer.

Four of the 10 phases of the strategy involved training sessions with the farmers. The following aspects of those sessions can be highlighted:

1. Training sessions should have little time between them (phases $4,6,7,8$ ) so that the process is kept coherent. It is important to periodically check the farmers as they usually have doubts about how to input data or check reports in the DSS. If there are errors in the input of data, they should be corrected as soon as possible to avoid repetition and learning bad habits. 
2. During the activities of collaboratively building the model (phase 4) it is important to mention that the model cannot be exactly the same as the system, as the model will lack certain aspects that exist in the real system (e.g., climate or residues) and include other aspects not taken into account in the real system (e.g., the costs of water). During the experience the farmers were aware that their systems are dynamic, but did not know about diagrams that could represent them. By including them in the construction of the simulation model they became engaged in the experience and had a representation methodology that they can try in other systems.

3. When playing the serious video game, the farmers simulate the decision-making processes which they usually perform on their farms (phase 6), and the tutor recommends challenges that increase their difficulty as the farmers gain expertise. An initial challenge is to keep a single animal alive for 6 months and then manage the reproduction and breeding process of the animal. A more advanced challenge requires the player to duplicate his initial money or to buy enough animals to fill the stable. Players gain get confidence in the use of the tools by overcoming those incremental challenges with the aid of the tutor.

4. In phases 6,7 , and 8 it is recommended to check the model to solve questions about the structure of the system. The activities in those phases therefore complement each other, that is, the farmer gains deeper and more detailed understanding of the tools with every phase he completes.

\subsection{Measurement of the Appropriation of the DSS}

Phase 10 of the strategy measures the achieved appropriation of the project. For this the DSS generates tracking reports that show the use that farmers made of the DSS, i.e., the number of days that they used it to register events of their productive system.

The production systems of the farmers who participated in the implementation of the strategy are either Dairy or Full Cycle. Because of this the minimal expected percentage of appropriation was calculated based on the milking event, as it is the most common event. As lactating cows produce milk for about 9 months, it would be expected for a farmer to record data on the system on $75 \%$ of the days of the year.

However, farmers are allowed to register data every 2 days for flexibility, which means that $37.5 \%$ is the minimal expected percentage of use to consider appropriation. The other events are not taken into account for this calculation as none of them usually happens more than 12 times a year.

As a summary, Table 4 shows the categories of animals that are usually found on a farm according to its productive system. The numbers show for how many days in a year each event is expected to happen for each category (Buying, Selling, and Dying are not included in the table as they are not periodic because they are only applied once in the productive system).

Table 4. Categories of animals and number of days to record data according to the productive system.

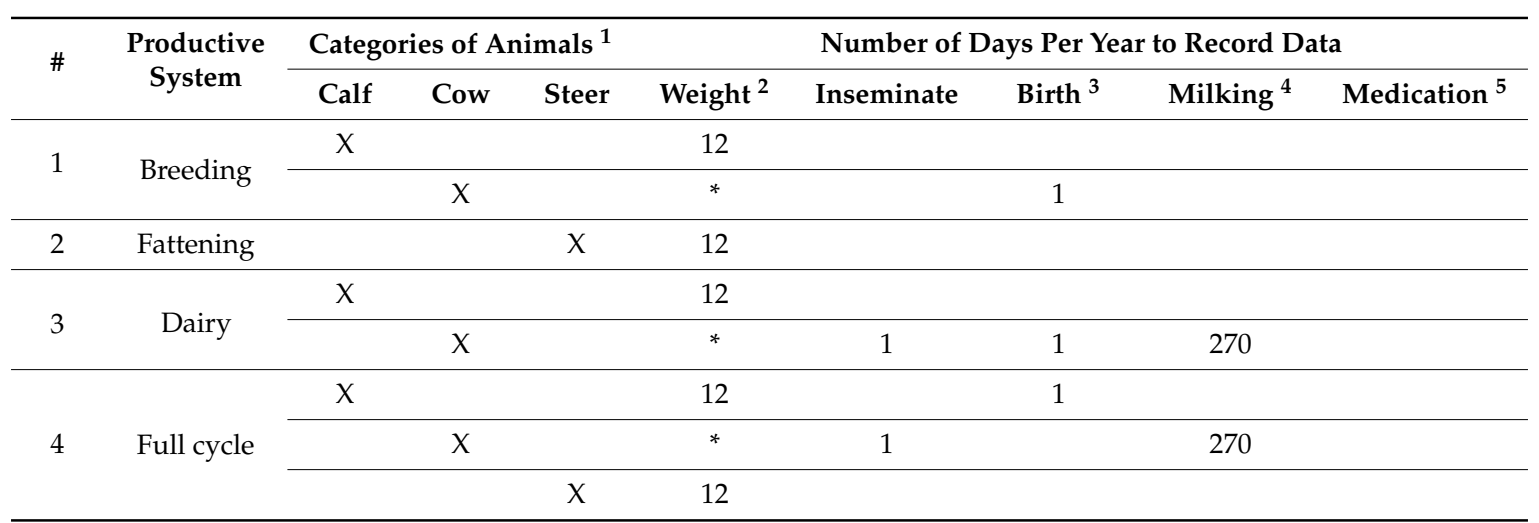

* The farmer must control the cows' weight. If the cows are not for fattening, are sold at the end of production.

${ }^{1}$ The bull is not included as it is weighted and vaccinated infrequently. ${ }^{2}$ Calves are weighed every month. ${ }^{3}$ Births are managed so that they happen once a year, and for that the cow is healthy and have milk for the calf. ${ }^{4}$ Manage the daily production of milk. ${ }^{5}$ Medicine is only administered when necessary. 
The appropriation of each farmer is calculated based on the number of days the farmer adds data to the DSS, and that in turn allows the calculation of the farmers who appropriated the DSS:

1. Percentage of appropriation: the ratio between the number of days that the farmer autonomously used the system and the number of days that passed since the aided phase finished.

2. Percentage of appropriated farmers: the ratio between the number of farmers with a percentage of appropriation greater than or equal to the minimal expected percentage of appropriation and the total number of participating farmers.

Percentage of appropriation $=($ Days with autonomous use $) /($ Total days with autonomy $)$

Percentage of appropriated $=($ farmers with percentage of appropriation greater than or equal to the minimal)/(number of participating farmer)

Table 5 summarizes the participation results after 22 months of autonomy (phase 9). The Table 5 shows the name and location, number of participating farmers, number of appropriated farmers, percentage of appropriated farmers, and percentage of appropriation of every appropriated farmer for each community. On average the percentage of appropriated farmers is 34 , as 11 of the 32 farmers have a percentage of appropriation greater than the minimal expected percentage of use to consider appropriation (37.5\%). This is an acceptable percentage if you take the cultural rooting, resistance to change, and personal, social and cultural patterns expressed in the introduction into account.

Table 5. Participating communities and results.

\begin{tabular}{cccccc}
\hline$\#$ & Community & $\begin{array}{c}\text { Number of } \\
\text { Farmers }\end{array}$ & $\begin{array}{c}\text { Number of Farmers } \\
\text { with Appropriation } \\
>=\mathbf{3 7 . 5 \%}\end{array}$ & $\begin{array}{c}\text { Percentage of } \\
\text { Appropriated } \\
\text { Farmers }\end{array}$ & $\begin{array}{c}\text { Percentage of } \\
\text { Appropriation of } \\
\text { Each Farmer }\end{array}$ \\
\hline 1 & La Fortuna (Lebrija) & 7 & 2 & $29 \%$ & $56 \%$ and $69 \%$ \\
2 & La Vega (Valle de San José) & 7 & 2 & $29 \%$ & $59 \%$ and $61 \%$ \\
3 & Portugal (Lebrija) & 8 & 3 & $38 \%$ & $58 \%$ and $60 \%$ and $62 \%$ \\
4 & San Lorenzo (Lebrija) & 5 & 2 & $40 \%$ & $64 \%$ and $63 \%$ \\
5 & San Mateo (Betulia) & 5 & 2 & $40 \%$ & $67 \%$ and $75 \%$ \\
\hline & Total & 32 & 11 & - & - \\
\hline
\end{tabular}

\subsection{Evaluation of the Acceptance of the DSS}

As a complement to the use of measurements of the DSS a poll was applied to the participants as a way to evaluate the strategy. The instrument measures the following four aspects:

1. The first aspect is related to the reasons that led the farmers to using the DSS. Figure 9 shows that most of the appropriated farmers use the DSS because it is easy to use and allows handling large amounts of data.

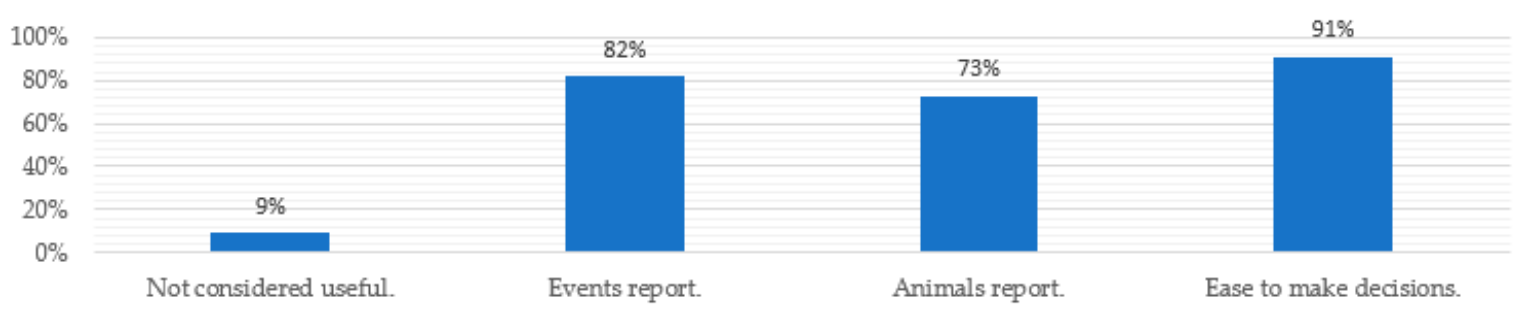

Figure 9. Reasons for using the DSS and considering it useful.

2. The second aspect is related to the reasons that led the farmers to considering the DSS useful. Figure 10 shows that most farmers found the DSS useful because of the reports it generates and because it makes decision making easier. 


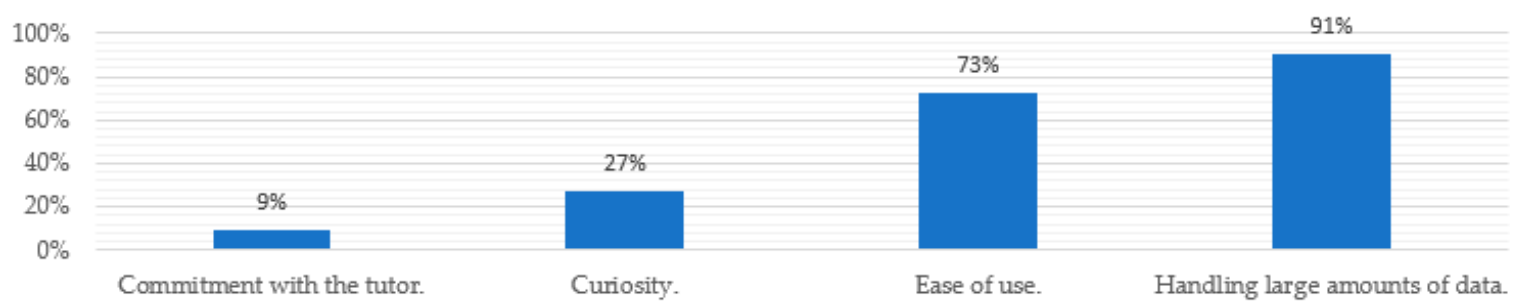

Figure 10. Reasons for using the DSS and considering it useful.

3. The third aspect involves evaluating 10 features of the DSS evaluated with a Likert scale (strongly disagree, disagree, neither agree nor disagree, agree, strongly agree). Figure 11 shows that most farmers strongly agree that the DSS meets all the proposed usability features. However, a future version can improve aspects related to the UI (attractiveness, size, and coloring), response time, input recognition, and the usefulness of the alerts.

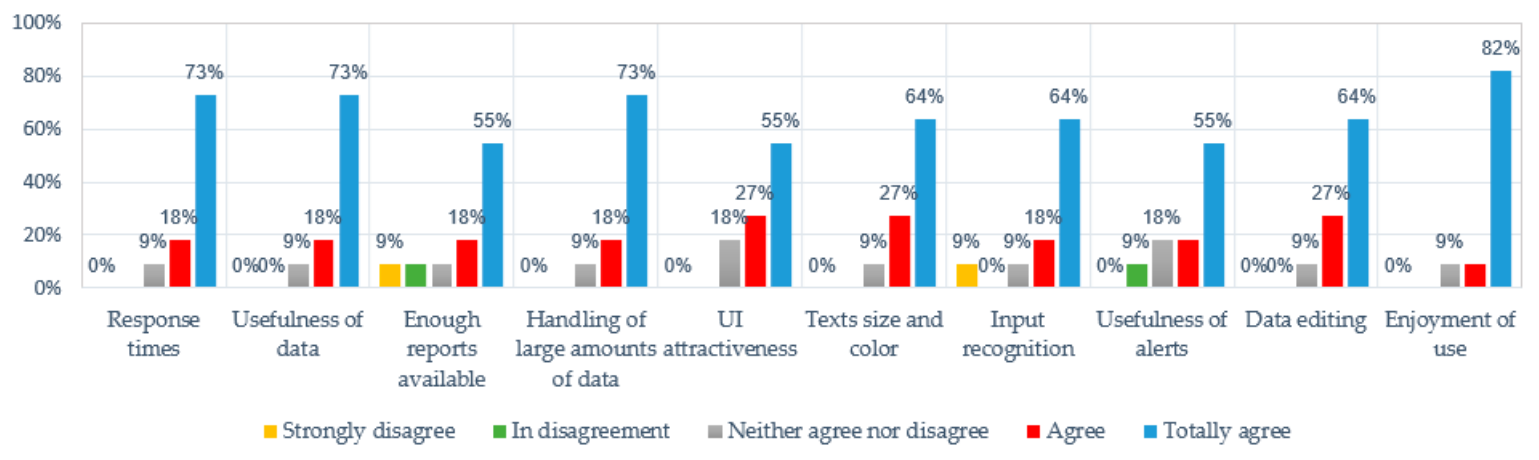

Figure 11. Results of the evaluation of the features.

4. The fourth aspect involve evaluating 10 functionalities of the DSS also evaluated with the Likert scale. Figure 12 shows that most farmers strongly agree with the importance of every functionality. Some features such as terrain management and insemination forecasting are not used a lot, and other features, including weighing, milking, and events reporting could be improved.

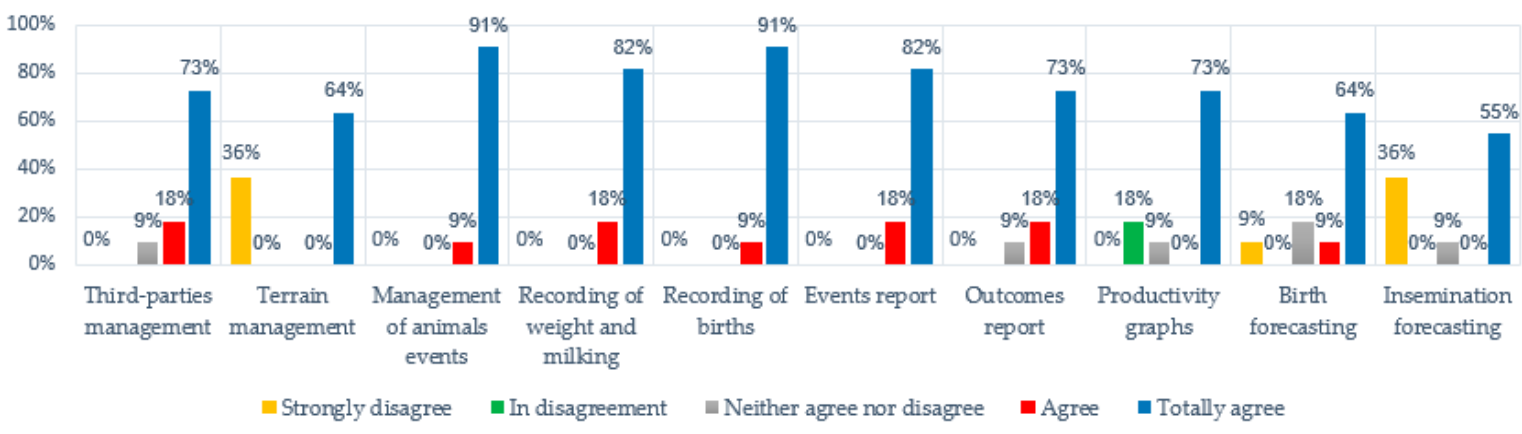

Figure 12. Results of the evaluation of functionalities.

\subsection{Evaluation for Abandoning the Strategy}

Some farmers did not appropriate the DSS. They were polled in order to understand the reasons behind this. The results of the poll (Figure 13) show that about half of the farmers who abandoned the strategy did so because they did not continue with their bovine production systems. That is directly related to rural abandonment [20]. Other farmers consider that the DSS is difficult to use, or that it is unnecessary to manage the farm. This shows that further efforts and alternative approaches are necessary to show farmers the importance of IT for managing processes. 


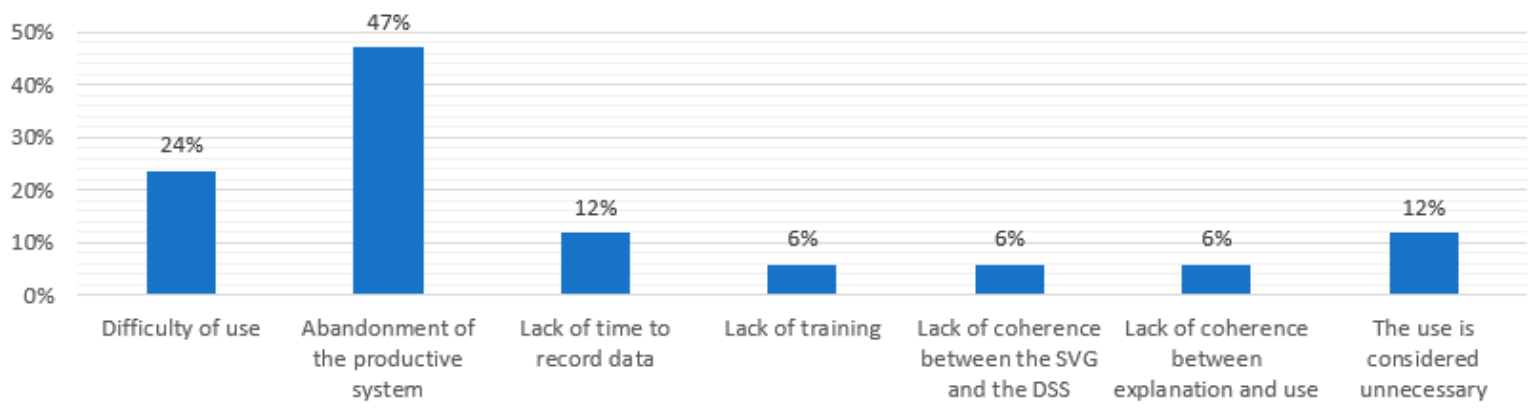

Figure 13. Reasons for abandoning the strategy.

\section{Discussion}

IT adoption is defined as the involvement of IT tools in processes to solve the need for information to improve the way the processes are run [21]. IT appropriation goes further than involving the tools, as it also means that these tools are used autonomously and with personal involvement [25]. Based on these definitions, the authors recognize that the proposed strategy for the rural sector achieved the appropriation of the DSS as it integrated tools, managed them to be used autonomously, and changed the way processes were executed.

Small bovine production systems are organizations that must begin to take advantage of technology by following IT adoption despite the limitations of resources as [50] where an intervention is required for an adoption process to be viable. In this study the intervention is executed by a tutor who accompanies the training and builds the tools.

The strategy included three IT tools with gamification elements and this helped to generate trust and involvement, which are especially important goals when training [51], in this case by senior adults. Both goals were achieved mainly because of the feedback that arose from the questions that the tutor or the farmer asked during the training regarding the obtained result.

The strategy helped the farmers to become process transformers while collaborating on the construction of a simulation model that represented their productive systems. This is as mentioned by Lundström and Lindblom [52], who recommend researchers to take the context of the participants into account when designing training strategies on the use of DSS for the agricultural sector.

The strategy follows what Somers and Stapleton [53] claim about IT appropriation being a challenge that needs to be tackled with strategies that improve the life conditions and benefit their users. The design and development research methodology focuses on the creation and use of tools to transform situations [42]. By including a simulation model and a serious video game to support the training sessions the strategy tools eased the way in which small bovine producers execute processes in their farms.

The case study methodology seeks to improve the way of using tools in the context of the community [54]. That happened when applying the proposed strategy, as the model allowed the organization of the training sessions and provided the farmers with flexibility in the use of the DSS while they were analyzing information from the video game as a way of acquiring skill before using the DSS to manage a real farm.

With the presented results it is possible to claim that the proposed strategy:

1. Met the researchers' intentions of (i) using a model with System Dynamics for the comprehension of the system, as expressed by Mejía and Cascante [16]; (ii) contributed to the use of this model to support the development of the software, as mentioned by Jaime [55] and Knox [56] to give clarity in the understanding of the production system and; (iii) mitigated the IT gap as it managed to achieve $34 \%$ of appropriation.

2. Involved the farmers in the process of raising awareness of the limitations of simulations, which are natural and depend on the purpose of the model [57]. The model allowed the understanding 
and representation with System Dynamics (mainly in the causal loop diagram) and the use of its equations to define rules in the serious game and to do forecasting in the DSS [48].

3. Integrated System Dynamics to support training, similarly to other works in the rural sector such as: (i) Protil and Barreiros [58] who represented critical processes during the commercialization of products of the cooperatives of agricultural communities; (ii) Basu and Sushanta [59] who showed reduction of poverty achieved thanks to the increase of capital and productivity in a region; (iii) Siregar et al. [60] who sought changes in politics based on the increase of agricultural production and access to technology; and (iv) Shikuku et al. [61] who prioritized productive strategies and technologies focused on the use of terrains to improve the return on investment.

4. Used a serious video game as a computational teaching tool that, according to Samaniego [62], enhances self-regulation of learning and plays a fundamental role in training processes with purposes similar to those shown in the works of: (i) Pacheco et al. [63] to ease the transfer of knowledge with the participants; (ii) Moras [64] to innovate in educational and social processes that transform and improve society, and (iii) Kessler et al. [65] to raise legislators' awareness of the amounts of information that are generated when dealing with the diverse issues that arise when managing terrains, and to develop best practices in the context of bovine producers.

\section{Conclusions}

The strategy proposes a set of phases for the appropriation of a DSS. These phases comprise a diagnostic on the use of IT and training sessions supported by a simulation model and the gamification, represented by a serious video game, which look for farmers to develop skills that improve with repeated use of the tools and contribute understanding of the advantages of using IT on their farms and with reducing cultural rooting. Some key factors of the strategy were:

1. The simulation model generated a common language for the tutor and the farmers, which delimited the scope of the tools, as well as it gave uniformity of use and served as a guideline in the training sessions. The cooperative iterative process of simulation and validation of the model was enriching for the farmers.

2. The serious video game allowed farmers to check the decisions they usually made on their farms and verify them in the DSS in a playful way. This query of data is an opportunity for farmers to understand that these decisions are usually forgotten or can be improved, and to become aware of the amount of data they usually handle and the importance of tracking decisions.

3. Working with communities allowed cooperation among participants both to share points of view and questions about the benefits of the DSS and to aid each other with the use of the DSS during the phases of autonomous use. Aligning the DSS with a model that the farmers approve and can inspect to solve questions about the structure of the system, showing them the amount of data generated with the serious videogame, and consulting of previous decisions in the DSS strengthened the appropriation process.

4. The help of the tutor while the farmer used the DSS to manage the data of his farm helped farmers to note the similarities between the experience on a real farm and the experience of the video game. This realization gave the farmers confidence in the use of the DSS. The confidence in the tools and the knowledge of the DSS that the farmers built with the help of the tutor and the simulated exercises made the farmers' autonomous use of the DSS easier.

The strategy was applied within the context of the previously mentioned regions, and its results can't be generalized to every small bovine producer as the productive, social, political, and economic conditions can change between regions.

The fact that farmers participated in the validation of the model helped them to use these tools in spite of their resistance to change, but the physical distance between the communities and the low number of farmers in each community limited the number of fellow participants of whom someone could ask questions or whose help someone could request, and reduced the motivation that would otherwise 
have been gained by watching other people use the software and talk about it. The appropriation could also have been lost in some cases because the existing network conditions required using asynchronous communication as some of the functionalities of the DSS, including parametrization and graphical reports, could only be used synchronously.

In future we expect to work with communities with their differences in processes, institutions, and unions to benefit more farmers with the strategy, increase the capacity of the technological infrastructure that supports the developed IT tool, allow networked work among farmers in the DSS, add functionalities to the DSS, and replicate the experience with other communities with particularities in their processes and other kinds of productive systems.

Author Contributions: Conceptualization, U.G.-P.; Strategy, U.G.-P.; Software, U.G.-P.; Validation, U.G.-P. and M.O.-H; Writing original draft preparation, U.G.-P.; Supervision, M.O.-H. and J.S.-I. All authors have read and agreed to the published version of the manuscript.

Funding: This research received no external funding.

Acknowledgments: The authors thank to: The bovine producers from the communities of La Fortuna, La Vega, Portugal, San Lorenzo and San Mateo for the trust placed in this project and the attention received in the training sessions carried out. Bolivarian Pontifical University (UPB), Autonomous University of Bucaramanga (UNAB) and University of the Balearic Islands (UIB) for providing the necessary conditions for the execution of the academic and research work of this proposal and The owner of a cattle farm in Betulia, Santander for providing his knowledge of livestock and production records to define the test data set.

Conflicts of Interest: The authors declare no conflict of interest.

\section{References}

1. Boz, I.; Akbay, C.; Jordan, G.; Kamalak, A. Measuring livestock farmers' effect on sustainable agricultural and rural development. Livest. Res. Rural Dev. 2005, 17, 73-90.

2. De Buck, A.; Van Rijn, I.; Wossink, G. Farmers' reasons for changing or not changing to more sustainable practices: An exploratory study of arable farming in the Netherlands. J. Agric. Educ. Ext. 2008, 7, 153-166. [CrossRef]

3. Budiyanto, C. Decision support systems development for an artificial insemination project in community based precision livestock farming. In Proceedings of the 10th International Conference on Compressors and their Systems, London, UK, 11-13 September 2017.

4. Whittenbury, K.; Davidson, P. Beyond adoption: The need for a broad understanding of factors that influence irrigators' decision-making. Rural Soc. 2009, 19, 4-16. [CrossRef]

5. Walmsley, B.; Oddy, V. Modelling systems to describe maternal productivity with the aim of improving beef production efficiency by eliciting practice change. Anim. Prod. Sci. 2018, 58, 193-205. [CrossRef]

6. Park, S. Digital inequalities in rural Australia: A double jeopardy of remoteness and social exclusion. Rural Stud. 2017, 54, 399-407. [CrossRef]

7. Chen, M.; Wichmann, B.; Luckert, M.; Winowiecki, L.; Förch, W.; Läderach, P. Diversification and intensification of agricultural adaptation from global to local scales. PLOS ONE 2018, 13. [CrossRef]

8. Arévalo, J.; Bayona, R.; Rico, D. El problema de la brecha tecnológica: Un asunto de cultura. Rev. Sinapsis 2015, 7, 35-43.

9. Zona-Ortiz, T.; Fajardo-Toro, C.H.; Aguilar, C. Propuesta de un Marco general para el despliegue de ciudades inteligentes apoyado en el desarrollo de IoT en Colombia. RISTI-Rev. Iber. Sist. Tecnol. Inf. 2020, 28, 894-907.

10. Fedegan. Normativa General Agropecuaria. Available online: https://cutt.ly/Npwpg2Z (accessed on 30 June 2020).

11. Jara, R.; Russy, S.; Roco, L.; Fleming-Muñoz, D.; Engler, A. Factors affecting the adoption of agroforestry practices: Insights from silvopastoral system of Colombia. Forests 2020, 11, 648. [CrossRef]

12. Frias-Navarro, R.; Montoya-Restrepo, L. Understanding knowledge creation processes among rural communities in post-conflict settings in Colombia. Knowl. Manag. E-Learn. 2020, 12, 231-255. [CrossRef]

13. Gobernación de Santander. Plan. de Desarrollo Social y Económico 2016-2019; Gobernación de Santander: Bucaramanga, Colombia, 2016.

14. United Nations Development Programme. ¿Qué es el Índice de Pobreza Multidimensional? Available online: http://hdr.undp.org/en/node/2515 (accessed on 2 August 2020). 
15. Fernández, B.; González-Busto, B.; Castaño, Y. The Dynamics of growth in Franchising. J. Mark. Channels 2013, 20, 2-24. [CrossRef]

16. Mejía, A.; Cascante, M. Hacia una dinámica de sistemas crítica: Un marco conceptual para investigación y una ilustración en educación. In Proceedings of the Fifth Latin American Congress of Systems Dynamics, Buenos Aires, Argentina, 7-10 November 2007.

17. Checkland, P.; Ornelas, M. Los sistemas de información y el pensamiento de sistemas: ¿Tiempo de unirse? Col. Sonora 1994, 7, 125-140.

18. Gómez-Prada, U.; Orellana-Hernández, M.; Salinas-Ibáñez, J. Apropiación de sistemas de tecnologías de la información para toma de decisiones de productores agroindustriales basada en videojuegos serios. Una revisión. Inf. Tecnol. 2019, 30, 331-340. [CrossRef]

19. Chaveau, B.; Vergara, S. Proyecto Piloto de Escuelas Rurales de Informática y Ciudadanía: Un Modelo de Transformación Social en Chile, España; Publicaciones y Ediciones de la Universidad de Barcelona: Barcelona, Spain, 2011.

20. Ortiz, R.; Franco, M. Políticas educativas de TIC en Colombia: Entre la inclusión digital y formas de transformación social. Pedagog. Saberes 2018, 48, 9-25. [CrossRef]

21. Erumban, A.; De Jong, S. Cross-country differences in ICT adoption: A consequence of culture. J. World Bus. 2006, 41, 302-314. [CrossRef]

22. Cobo, C. Aprendizaje Adaptable y Apropiación Tecnológica: Reflexiones Prospectivas. 2008. Available online: http://laisumedu.org/DESIN_Ibarra/autoestudio3/ponencias/ponencia33.pdf (accessed on 2 March 2020).

23. Daza, L.; Hernández, C.; Quijano, A.; Serna, J. Plan Estratégico del Departamento de Santander. 2017. Available online: https://cutt.ly/LutBXUM (accessed on 15 September 2020).

24. Sandia, B.; Luzardo, M.; Aguilar, A. Una visión del nivel de apropiación de las TIC en la Universidad de Los Andes. Mérida-Venezuela. Sist. Inf. Cient. 2016, 20, 99-112.

25. Salemink, K.; Strijker, D.; Bosworth, G. The participation society and its inability to correct the failure of market players to deliver adequate service levels in rural areas. Telecommun. Policy 2018, 42, 757-765. [CrossRef]

26. Suárez-Guerrero, C.; Rivera-Vargas, P.; Rebour, M. Preguntas educativas para la tecnología digital como respuesta. Rev. Electrón. Tecnol. Educ. 2020, 73, 7-22. [CrossRef]

27. Zeng, H.; Xia, W.; Wang, J.; Wang, R. Approach of ICT in Education for Rural Development: Good Practices from Developing Countries; SAGE Publications India: New Delhi, India, 2015.

28. Harris, R.W. Information and Communication Technologies for Poverty Alleviation; United Nations Development Programme (UNDP), Asia-Pacific Development Information Programme: Kuala Lumpur, Malaysia, 2004.

29. Fritz, S.; See, L.; Bayas, J.C.L.; Waldner, F.; Jacques, D.; Becker-Reshef, I.; Whitcraft, A.; Baruth, B.; Bonifacio, R.; Crutchfield, J.; et al. A comparison of global agricultural monitoring systems and current gaps. Agric. Syst. 2019, 168, 258-272. [CrossRef]

30. Universidad Nacional de Colombia. Agroindustria y Comercio Desaprovechan TIC. 2014. Available online: https://cutt.ly/uutBgLB (accessed on 19 September 2020).

31. Gómez, U.; Andrade, H.; Vásquez, C. Lineamientos metodológicos para construir ambientes de aprendizaje en sistemas productivos agropecuarios soportados en dinámica de sistemas. Inf. Tecnol. 2015, 25, 125-136. [CrossRef]

32. Cortés, H.; Aguilar, C.; Vera, R. Sistemas Bovinos de Doble Propósito en el Trópico-Modelo de Simulación; Pontificia Universidad Católica de Chile, Facultad de Agronomía e Ingeniería Forestal: Santiago, Chile, 2004.

33. Markauskaite, L.; Kelly, N.; Jacobson, M. Model-based knowing: How do students ground their understanding about climate systems in agent-based computer models? Res. Sci. Educ. 2020, 50, 53-77. [CrossRef]

34. Forrester, J. Industrial Dynamics; M.I.T Press: Cambridge, MA, USA; Wiley: New York, NY, USA, 1961; ISBN 9781614275336.

35. Maani, K. System dynamics and organizational learning, System Dynamics. In Encyclopedia of Complexity and Systems Science; Meyers, R., Ed.; Springer: Berlin, Germany, 2020; ISBN 978149398790.

36. Andrade, H.; Dyner, I.; Espinosa, A.; López, H.; Sotaquirá, R. Pensamiento Sistémico, Diversidad en Búsqueda de Unidad; Universidad Industrial de Santander: Bucaramanga, Colombia, 2001; ISBN 9589318789.

37. Schell, J. The Art of Game Design: A Book of Lenses, 2nd ed.; CRC Press: Boca Raton, FL, USA, 2014; ISBN 9780123694966. 
38. Gros, B. Certezas e interrogantes acerca del uso de los videojuegos para el aprendizaje. Comunicación 2009, 7, 251-264.

39. Fisher, J.; Farré, I.; Dray, A.; Khimashia, N.; Perez, P. Serious games to explore uncertainty of future farms. In Proceedings of the 16th Agronomy Conference 2012, New South Wales, Australia, 14-18 October 2012.

40. Pressman, R. Ingeniería del Software, 7th ed.; Mc Graw Hill: Mexico City, Mexico, 2014; ISBN 9786073206037.

41. Machado, C.; Berger, H. Uso de modelos de simulación para asistir decisiones en sistemas de producción de carne. Rev. Argent. Prod. Anim. 2012, 32, 87-105.

42. Salinas, J.; Negre, F.; Gallardo, T.; Escandell, C. Modelos didácticos en entornos virtuales de formación: Identificación y valoración de elementos y relaciones en los diferentes niveles de gestión. In Proceedings of the Internation Congress Edutec, Tarragona, Spain, 29 May-1 June 2016.

43. Richey, R.; Klein, D. Design and development research. In Handbook of Research on Educational Communications and Technology, 4th ed.; Spector, J., Merrill, M., Elen, J., Bishop, M., Eds.; Springer: New York, NY, USA, 2014.

44. Merriam, S. Qualitative Research. A Guide to Design and Implementation, 4th ed.; Jossey-Bass: San Francisco, CA, USA, 2015; ISBN 9781119003618.

45. Kruchten, P. The Rational Unified Process: An Introduction, 3rd ed.; Addison-Wesley Professional: New York, NY, USA, 2004; ISBN 03211977704.

46. Victoria, R.; Utrilla, S.; Santamaría, A. Aprendizaje basado en juegos, una alternativa viable para la enseñanza significativa de la sustentabilidad. Rev. Electrón. Sobre Educ. Media Super. 2017, 7, 4.

47. Gómez, U.; Orellana, M.; Salinas, J. Apropiación de TI para la toma de decisiones de pequeños productores bovinos-Diagnóstico de ganaderos beneficiarios. In Proceedings of the International Congress Edutec, Lima, Peru, 23-25 October 2019.

48. Gómez, U.; Orellana, M.; Salinas, J. Systems dynamics and serious video games in an appropriation strategy of a decision support system of small bovine producers. Int. J. Interact. Mob. Technol. 2020, 14, 4-24. [CrossRef]

49. Andrade, H.; Lince, E.; Hernández, E.; Monsalve, A. Evolución: Herramienta software para modelado y simulación con dinámica de sistemas. Rev. Dinámica Sist. 2011, 4, 1-27.

50. Ghobakhloo, M.; Hong, T.; Sabouri, M.; Zulkifli, N. Strategies for successful information technology adoption in small and medium-sized enterprises. Information 2012, 3, 36-67. [CrossRef]

51. Papadakis, S. Evaluating a game-development approach to teach introductory programming concepts in secondary education. Int. J. Technol. Enhanc. Learn. 2020, 12, 127-145. [CrossRef]

52. Lundström, C.; Lindblom, J. Considering farmers' situated knowledge of using agricultural decision support systems (AgriDSS) to foster farming practices: The case of CropSAT. Agric. Syst. 2018, 159, 9-20. [CrossRef]

53. Somers, S.; Stapleton, L. E-Agricultural innovation using a humancentred systems lens, proposed conceptual framework. AI Soc. 2014, 29, 193-202. [CrossRef]

54. Hancock, D.; Algozzine, B. Doing Case Study Research: A Practical Guide for Beginning Researchers; Teachers College Press: New York, NY, USA, 2017; ISBN 9780807758137.

55. Jaime, R. Modelamiento semántico con Dinámica de Sistemas en el proceso de desarrollo de software. Rev. Ibérica Sist. Tecnol. Inf. 2012, 10, 19-33.

56. Knox, K. Constructing an 'Information Strategy' in Higher Education: Perceptions, Structure and Action. Ph.D. Thesis, Nottingham Trent University, Nottingham, UK, March 2015.

57. Featherston, C.; Doolan, M. Using system dynamics to inform scenario planning: A case study. In Proceedings of the 31st International Conference of the System Dynamics Society, Cambridge, MA, USA, 21-25 July 2013.

58. Protil, R.; Barreiros, R. Strategic control of agro-industrial cooperatives: A strategic map proposal. In Proceedings of the 30th International Conference of the System Dynamics Society, St. Gallen, Switzerland, 22-26 July 2012.

59. Basu, S.; Sushanta, M. When does growth trickle down to the poor? The Indian case. Camb. J. Econ. 2007, 32, 461-477. [CrossRef]

60. Siregar, P.; Supriatna, J.; Koestoer, R.; Harmantyo, D. System Dynamics Modeling of Land Use Change in West Kalimantan, Indonesia. Biotropia Southeast. Asian J. Trop. Biol. 2018, 25, 103-111. [CrossRef]

61. Shikuku, K.; Valdivia, R.; Paul, B.K.; Mwongera, C.; Winowiecki, L.; Läderach, P.; Herrero, M.; Silvestri, S. Prioritizing climate-smart livestock technologies in rural Tanzania: A minimum data approach. Agric. Syst. 2017, 151, 204-216. [CrossRef] 
62. Samaniego, R. Serious game as a way to boost self-regulated learning in higher education. Turk. Online J. Educ. Technol. 2017, 20, 625-630.

63. Amado Pacheco, M.A.; Avila Avila, W.; González Moreno, J.C.; González Lozano, F.A.; Gualdrón Diaz, M.I.; Insuasty Burbano, O.I.; Manrique Estupiñan, R.; Morales Amaya, J.A.; Peña Tinoco, H.; Prada Forero, L.E.; et al. Aspectos Metodológicos para la Construcción de un Modelo Computacional para la Transferencia y Enseñanza en la Agroindustria Panelera. 2018. Available online: https://cutt.ly/TpwEl0T (accessed on 3 June 2020).

64. Moras, J. Serious Games: Diseño de Videojuegos con una Agenda Educative; UOC: Barcelona, Spain, 2015.

65. Kessler, A. Be an African Farmer in the Game African Highland Farmer. 2016. Available online: https: //cutt.ly/4pwIxmt (accessed on 12 May 2020).

Publisher's Note: MDPI stays neutral with regard to jurisdictional claims in published maps and institutional affiliations.

(C) 2020 by the authors. Licensee MDPI, Basel, Switzerland. This article is an open access article distributed under the terms and conditions of the Creative Commons Attribution (CC BY) license (http://creativecommons.org/licenses/by/4.0/). 